J. Clin. Chem. Clin. Biochem.

Vol. 15, 1977, pp. 319-321

\title{
Distribution of Oestradiol Receptor Molecules in Human Kidney
}

\author{
By H. Bojar, R. Dreyfürst, K. Maar and W. Staib
}

Institut für Physiologische Chemie II (Direktor: Prof. Dr. W. Staib) und Urologische Klinik (Direktor: Prof. Dr. H. Dettmar) der Universität Düsseldorf

(Received October 19, 1976/January 11, 1977)

Summary: Experiments were performed to determine the distribution of oestrogen receptors in normal human kidney. Cytosols prepared from renal medulla and cortex were separately analyzed for oestrogen receptor molecules by agar gel electrophoresis. Oestrogen receptors could be demonstrated in both compartments of the organ. However, the experiments reveal that the medulla is the main locus of oestrogen receptors in human kidney.

\section{Verteilung der Östrogenrezeptoren in der Niere des Menschen}

Zusammenfassung: Die Verteilung der Östrogenrezeptoren in der normalen menschlichen Niere wurde untersucht. Cytosol, das von Nierenmark und Nierenrinde getrennt präpariert wurde, untersuchten wir mittels Agargel-Elektrophorese auf seinen Östrogenrezeptorgehalt. Östrogenrezeptoren konnten in beiden Kompartimenten des Organs nachgewiesen werden. Jedoch zeigen die Experimente deutlich, daß die Markregion als Hauptlokalisation der Östrogenrezeptoren in der menschlichen Niere anzusehen ist.

\section{Introduction}

Specific oestrogen-binding components were recently demonstrated in the cytosol of normal human kidney (1) as well as human kidney carcinoma (2). On the basis of the observed variability in the binding capacity and sucrose gradient sedimentation patterns of oestrogen binding components, prepared from tissue samples of different kidneys, it was assumed that inter-organ and/or intra-organ variations may exist. These observations prompted the investigation of a possible compartmentation of the oestrogen $\mathrm{binding}$ entities in this organ. The present communication describes considerable differences in the receptor content of cytosol from medulla and cortex of human kidney.

\section{Materials and Methods}

\section{Chemicals and Reagents}

$\left(6,7{ }^{3} \mathrm{H}\right.$ )oestradiol-17. $\beta(51 \mathrm{Ci} / \mathrm{mmol}=1887 \mathrm{G} \mathrm{Bq} / \mathrm{mmol})$ and Biofluor were obtained from New England Nuclear. Unlabelled 17. $\beta$-oestradiol was purchased from Calbiochem. Agar purum and bovine serum albumin were obtained from Behring, Marburg. All other chemicals were commercial preparations of analytical grade.

\section{Patients}

In 1976 four male patients with renal cell carcinoma, aged 61 to 73, were nephrectomized at the Urologische Kliniken der Universitäten Düsseldorf and Bonn. Specimens were taken from those parts of the kidney which, by histological examination, proved to be free of infiltrating tumour tissue.

Handling of Kidney Specimens and Preparation of Cytosols The procedures used have been described in detail earlier in this Journal (1).

\section{Agar Gel Electrophoresis}

The electrophoretic procedure was a slight modification (1) of the technique originally described by Wagner (3).

Protein Determination

Protein was estimated by Lowry's method (4) using bovine serum albumin as standard.

\section{Results and Discussion}

In order to investigate the distribution of the oestrogenbinding components in normal human kidney, the tissue was roughly dissected into medulla and cortex. Cytosol, separately prepared from both compartments of the organ, was applied to agar gel electrophoresis at low 
temperature. This technique is one of the most accurate and informative procedures available for oestrogen receptor assay in target tissue extracts of man, since it separates in the oestrogen-receptor complex from unbound hormone, characterizes the receptor molecule by its electrophoretic mobility, and discriminates between receptor and sex-hormone-binding globulin, which may be present in the tissue extract due to serum contamination (3). Isotopic profiles of the oestradiol-binding components separated by agar gel electrophoresis are shown in figure 1. Specific binding of $\left[{ }^{3} \mathrm{H}\right]$ oestradiol-17 $\beta$ is indicated by the differences between the isotopic profiles of total (closed circles) and non-specific binding (open circles). In both compartments of human kidney, medulla (Fig. 1, profile A) and cortex (Fig. 1, profile B), specific binding of $17 \beta$-oestradiol could be demonstrated in the receptor region of the gel. However, it can clearly be seen that the majority of the oestradiol receptor sites of human kidney are located in the medulla. In this compartment the concentration of binding sites, assuming that each site binds only one molecule of $17 \beta$-oestradiol, amounted to $219.8 \pm 31.7 \mathrm{fmol} / \mathrm{mg}$ of cytosol protein. In contrast, cytosol prepared from kidney cortex contained only $29.9 \pm 3.8 \mathrm{fmol} / \mathrm{mg}$ $(p<0.001)$. One has to conisider that cytosols prepared from different regions of an organ may differ in the degree of contamination with blood proteins which may complicate the accuracy of the estimation of the receptor concentration based on total cytosol protein. However, routinely performed measurements of the hemoglobin content of cytosols did not show major differences in the degree of contamination of cytosols prepared from medulla and cortex. The hemoglobin concentration of cytosol prepared from cortex and
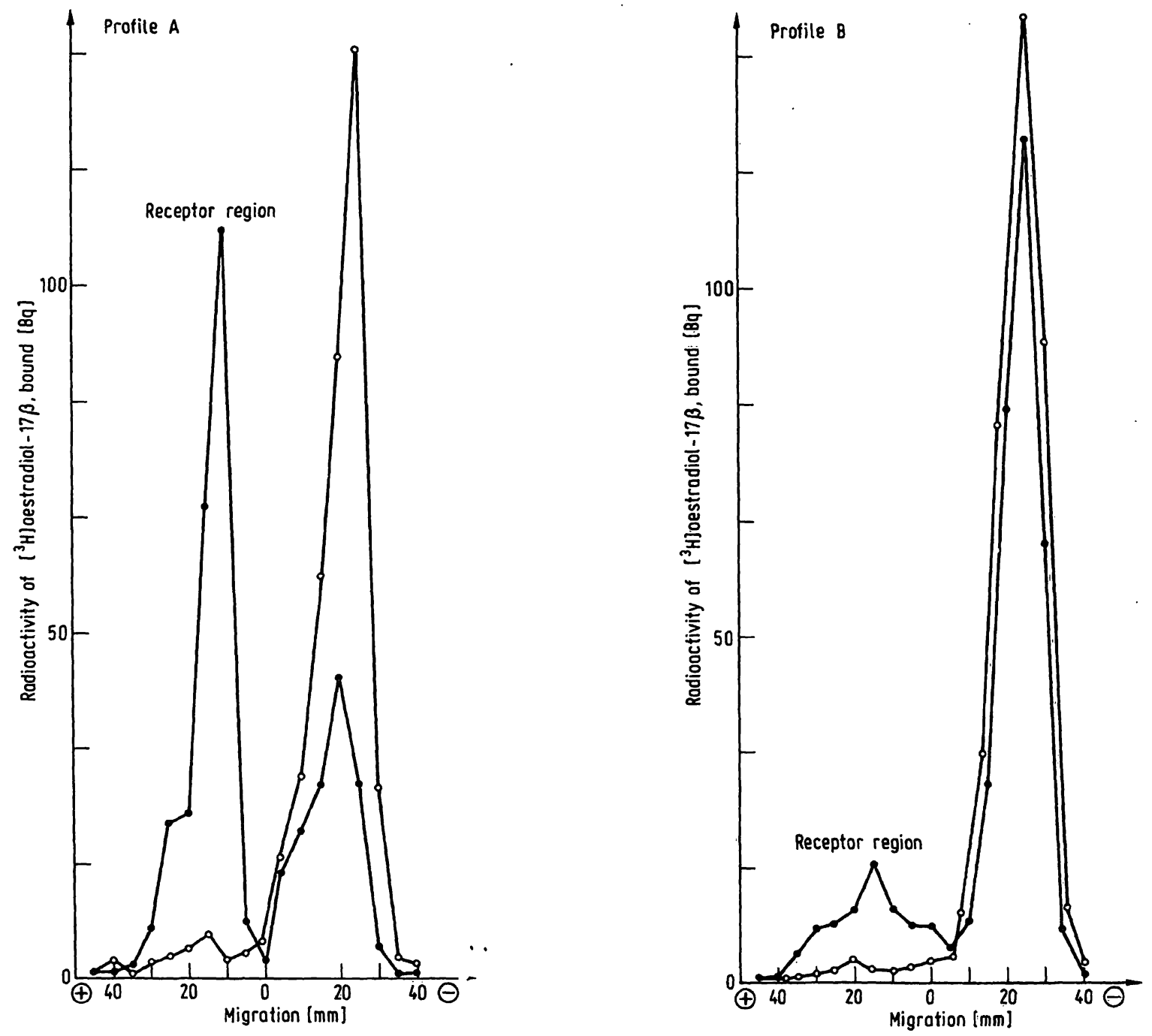

Fig. 1. Isotopic profiles of oestradiol-binding components, separated by agar gel electrophoresis of cytosols, separately prepared from medulla (profile A) and cortex (profile B) of normal human kidney. Cytosols $(0.5 \mathrm{ml})$ prepared in Tris buffer $C$ were reacted in vitro with $3.4 \mathrm{nmol} / 1\left[^{3} \mathrm{H}\right]$ oestradiol- $17 \beta$ for $18 \mathrm{~h}$ at $0{ }^{\circ} \mathrm{C}$, either alone $(\bullet-\bullet)$ or in the presence of a 100 -fold excess of unlabelled 17 $\beta$-oestadiol $(0-0)$. Conditions of agar gel electrophoresis: $50 \mu \mathrm{l}$ portions of labelled cytosol applied to $10 \mathrm{~g} / \mathrm{A}$ agar gel, $130 \mathrm{~mA}, 90 \mathrm{~min}, 3-4^{\circ} \mathrm{C}$ (gel temperature in receptor region), $5 \mathrm{~mm}$ sections counted after in-vial combustion. 
medulla was found to be $0.756 \pm 0.173$ and $0.977 \pm 0.299$ $\mathrm{g} / \mathrm{l}$, respectively (mean \pm SEM of 4 determinations).

Based on our previous observations of a considerable variability in the oestradiol-binding capacity of cytosols prepared from different kidney specimens, we speculated that the binding sites were not evenly distributed among medulla and cortex (1). The results presented here strongly confirm this idea. The finding raises the following two interdependent questions:

1. Is the occurrence of the identified receptor molecules restricted to a distinct cell population, as for instance cells of the collecting tubules or the loops of Henle?

2. What is the physiological significance of such receptor sites in the medulla?

\section{References}

1. Bojar, H., Balzer, K., Dreyfürst, R., Staib, W. \& Wittliff, J. L. (1976), this j. 14, 515-520.

2. Bojar, H., Dreyfürst, R., Balzer, K., Staib, W. \& Wittliff, J. L. (1976), this j. 14, 521-526.

3. Wagner, R. K. (1972), Hoppe Seyler's Z. Physiol. Chem. 353, 1235-1245.

4. Lowry, O. H., Rosebrough, A. L., Farr, A. L. \& Randall, R. J. (1951), J. Biol. Chem. 193, 265-275.
A number of investigations indicate that oestrogens exhibit a marked anti-natriuretic effect in various species including man $(5,6,7)$. The preferential medullary localisation of the oestrogen receptors raises the possibility of the collecting tubule and/or the loop of Henle (ascending limb?) as the predominant site(s) of action for oestrogens. Considering the low levels of oestrogen receptors in kidney cortex, we are left with two possible interpretations. Binding of $17 \beta$-oestradiol by kidney cortex cytosol may be attributed to autochthonous cortical receptor sites or to medullary receptors attributable to collecting tubules, the terminal branches of which extent into the cortex. A decision between these two explanations will require autoradiographic experiments.
5. Johnson, J. A., Davis, J. O., Baumber, J. S. \& Schneider, E. G. (1970), Am. J. Physiol. 219, 1691-1697.

6. Preedy, J. R. K. \& Aitken, E. H. (1956), J. Clin. Invest. 35, 423-429.

7. De Vries, J. R., Ludens, J. H. \& Fanestiel, D. D. (1972), Kidney International 2, 95-100.

Dr. Hans Bojar Institut für Physiologische Chemie II der Universität Düsseldorf

Moorenstraße 5

D-4000 Düsseldorf 
